\title{
PENGARUH SBI, KURS, DAN INFLASI TERHADAP SAHAM INDEKS LQ45 DENGAN TRADE WAR SEBAGAI VARIABEL MODERATING
}

\author{
Muhammad Isa Alamsyahbana \\ Sekolah Tinggi Ilmu Ekonomi (STIE) Pembangungan Tanjungpinang \\ albanapengusahamuda@gmail.com
}

\begin{abstract}
Abstrak: Pasar modal merupakan elemen penting dalam mengukur suatu kondisi ekonomi negara. Dengan pentingnya peran pasar modal, diharapkan peran masyarakat dapat tumbuh sehingga dapat berperan aktif dalam transaksi di pasar modal. Dengan adanya kondisi dimana suku bunga SBI yang terus meningkat, kurs valas yang juga tinggi serta adanya inflasi, maka peneliti hendak menguji pengaruhnya terhadap kinerja saham indeks LQ45, dan ditambahkan variabel trade war sebagai variabel moderating periode 2016-2018. Hasil penelitian menunjukkan bahwa hanya variabel kurs valuta asing yang memiliki pengaruh signigfikan terhadap kinerja saham indeks. Sedangkan variabel suku bunga SBI dan infasi tidak berpengaruh secara signifikan. Adapun variabel moderatingnya semua mampu dimoderasi oleh trade war, namun tidak memiliki hasil yang signifikan sehingga tergolong sebagai pure moderasi. Adapun masukan kepada peneliti mendatang untuk menambah tahun penelitian sebab perang dagang yang terjadi masih berlangsung panjang. Selain itu, bangsa Indonesia juga perlu mempersiapkan diri untuk menghadapi perang dagang dalam fase berikutnya, terutama dalam ekonomi makro dan hubungan internasional.
\end{abstract}

Kata kunci: Perang dagang, LQ45, SBI rate, kurs valuta asing, inflasi

Abstract:Capital market is important elements to see the economic condition for a nations. Because of it, we hope people in this country can join in capital market transactions to increase our dominations. In fluctuating conditions with SBI rate, kurs valas, and inflations, it will be effects to LQ45 indeks performance. And for this reasearch, we included trade war as moderating effects. As a result, only kurs valas make a signifations on regresion with indeks LQ45 performance. SBI rate and inflations doesn't have a significations effects in regression. And for moderating effects, the result is no one of hypotesis can prove, and this model as be a pure moderating. Our suggest to next, may be you can add more years for samples and to see a trade wars in anothers perspective like macro economics and international economics.

Keywords: Trade war, LQ45 Performance index, SBI rate, Kurs Valas, Inflations

\section{PENDAHULUAN}

Pasar secara umum dapat diartikan sebagai suatu tempat bertemunya antara penjual dan pembeli dalam satu waktu untuk suatu barang dan transaksi terjadi dengan kesepatakan antara kedua belah pihak. Adapun pasar yang bersifat produktif dengan maksud untuk investasi dikenal dengan nama pasar modal. Pengertian pasar modal tidak jauh berbeda dengan pasar pada umumnya, yaitu suatu tempat perdagangan yang mempertemukan antara penjual dan pembeli, namun barang yang dijual berupa surat-surat berharga seperti saham maupun obligasi yang merupakan surat kepemilikan ataupun surat hutang perusahaan dalam rangka kegiatan investasi bagi pembeli dan menjadi tambahan modal bagi pemilik perusahaan. Pasar modal 
disetiap negara memiliki peran yang fundamental, karena secara makro ekonomi, pasar modal memiliki peran sebagai media investasi (baik bagi pemerintah maupun swasta), selain dari adanya konsumsi, belanja pemerintah maupun kegiatan ekspor dan import. Dengan pasar modal yang sehat, maka diharapakan menjadi salah satu indikator bahwa negara memiliki keuangan yang baik. Ketika perusahaan yang berada di dalam pasar modal memiliki keuangan yang baik, maka kehadiran perusahaan tersebut akan memberikan berbagai kontribusi, seperti dibukannya lapangan pekerjaan bagi masyarakat yang berada di lingkungannya dan perusahaan tersebut akan memberikan kontribusi berupa pajak yang lebih besar sebagai pemasukan terhadap daerah.

Dalam mengukur kinerja suatu pasar modal, tentu ada ukuran atau indikator yang menjadi suatu acuan. Dari berbagai macam cara untuk melihat kondisi suatu pasar modal di suatu negara, salah satunya dengan memperhatikan kondisi kinerja saham indeks. Dengan memperhatikan kinerja saham indeks, maka seorang pembaca dapat melihat gambaran secara umum tentang kondisi pasar modal di suatu negara. Hal ini disebabkan karena saham indeks merupakan suatu nilai yang telah diperhitungan dengan metode khusus dimana outputnya akan menunjukkan suatu nilai akumulasi dari seluruh saham yang beredar dipasar modal. Di Indonesia, terdapat berbagai laporan kinerja saham indeks, seperti Indeks Harga
Saham Gabungan (IHSG), indeks LQ45, Jakarta Islamic Indeks 70, ISSI dan lain sebagainya. Masing-masing indeks memiliki keunggulan dan ciri khas masing-masing sehingga diharapkan bagi para pihak yang berkepentingan dapat menyesuaikan dalam membaca indeks yang dibutuhkan.

Setidaknya terdiri atas 2 pendekatan faktor ekonomi untuk melihat perubahan dipasar modal, yaitu faktor ekonomi secara makro dan mikro. Faktor ekonomi secara makro tersebut merupakan gabungan dari beberapa faktor fundamental ekonomi yang diduga berpengaruh terhadap kinerja saham indeks seperti laju pertumbuhan ekonomi, inflasi, nilai kurs valuta asing, dan tingkat suku bunga Sertifikat Bank Indonesia. Terjaganya stabilitas ekonomi makro secara berkesinambungan diyakini akan meningkatkan kepercayaan berbagai pihak baik dari internasional maupun dalam negeri terhadap perekonomian negara yang pada gilirannya akan memberikan dampak berupa nilai tambah terhadap peningkatan pendapatan dan kesejahteraan masyarakat melalui penciptaan atau pertumbuhan ekonomi yang tinggi serta berkualitas. Sedangkan faktor ekonomi secara mikro dalam hal ini merupakan berbagai faktor yang terjadi pada internal perusahaan seperti penerapan Good Corporate Governance (GCG), pengukuran likuiditas, profitabilitas, return on assets, return on investment, pembagian deviden dan lain sebagainya. Dari berbagai faktor-faktor 
diatas yang menjadi indikator dalam mengukur harga saham di pasar modal.

Fenomena yang terjadi ketika penelitian ini dibuat yaitu kinerja saham indeks LQ45 yang merupakan suatu indeks dengan kondisi perusahaan-perusahaan yang paling likuid dengan profitabilitas yang tinggi mengalami koreksi yang sangat dalam atau menurunnya performa secara terus menerus, dapat menyebabkan investor menjadi ragu untuk berinvestasi di pasar modal Indonesia. Adapun fenomena lainnya yaitu suku bunga Sertifikat Bank Indonesia yang selalu meningkat setiap waktunya, nilai rasio inflasi serta nilai kurs valuta asing yang terus meningkat hingga mencapai nilai Rp. 15.286 / US Dollar pada tanggal 25 Oktober 2018 sebagai nilai tertinggi penurunan kurs Rupiah terhadap US Dollar. Sedangkan inflasi juga mengalami fluktuasi selama waktu pengukuran. Adapun ringkasannya dapat dilihat sebagaimana tabel berikut:

Tabel 1

Kondisi Indeks LQ45, Suku Bunga SBI, Inflasi dan kurs

\begin{tabular}{|c|c|c|c|c|}
\hline Periode & $\begin{array}{c}\text { Indeks } \\
\text { LQ45 }\end{array}$ & $\begin{array}{c}\text { Suku } \\
\text { Bunga } \\
\text { SBI }\end{array}$ & Kurs & Inflasi \\
\hline $\begin{array}{c}\text { Jan } \\
2018\end{array}$ & $1.105,762$ & $4,25 \%$ & 13.610 & $3,25 \%$ \\
\hline $\begin{array}{c}\text { Feb } \\
2018\end{array}$ & $1.100,281$ & $4,25 \%$ & 13.776 & $3,18 \%$ \\
\hline $\begin{array}{c}\text { Mar } \\
2018\end{array}$ & $1.005,678$ & $4,25 \%$ & 13.862 & $3,40 \%$ \\
\hline $\begin{array}{c}\text { April } \\
2018\end{array}$ & 958,413 & $4,50 \%$ & 14.000 & $3,41 \%$ \\
\hline $\begin{array}{c}\text { Mei } \\
2018\end{array}$ & 953,592 & $4,75 \%$ & 14.276 & $3,23 \%$ \\
\hline $\begin{array}{c}\text { Jun } \\
2018\end{array}$ & 908,967 & $5,25 \%$ & 14.476 & $3,12 \%$ \\
\hline Jul 2018 & 933,891 & $5,25 \%$ & 14.614 & $3,18 \%$ \\
\hline
\end{tabular}

Sumber: Bank Indonesia, idx.co.id dan pusatdata.kontan.co.id
Adapun variabel yang menjadi pembeda dengan berbagai penelitian sebelumnya adalah penggunaan variabel trade war atau perang dagang sebagai variabel moderating dalam mempengaruhi (memperkuat ataupun memperlemah) hubungan antara variabel independen dan variabel dependen yang telah peneliti pilih. Adapun fenomena trade war atau perang dagang antara Amerika dengan beberapa negara lainnya bermula sejak terpilihnya presiden Amerika yang baru, yaitu Donald Trump pada tahun 2016. Ia berusaha untuk menepati janji-janji kampanyenya untuk menjadikan negara Amerika kembali berjaya dengan slogan“America First! Make America Great Again”, maka dikeluarkanlah berbagai kebijakan sebagai langkah nyata dalam upayanya mewujudkan negara Amerika yang hebat. Adapun beberapa alasan dilakukannya trade war oleh Amerika terhadap China, setidaknya terdiri atas tiga alasan, yaitu terlalu besarnya neraca perdagangan China sehingga menyebabkan depressing job creations dan terjadinya defisit perdangan Amerika terhadap China. Selanjutnya adanya dugaan pihak China menggunakan metode yang illegal dan tidak adil dalam transfer teknologi dan dalam pemberian harga yang murah sehingga menyebabkan ketatnya persaingan. Dan alasan ke tiga yaitu ketakutan Amerika atas China dalam dugaan menjaga keamanan nasional dan kedudukan internationalnya. Dengan adanya trade war antara ke dua negara yang memiliki peringkat 
nomor satu dan dua dalam perdangan pasar dunia, tentu dapat memiliki dampak dan resiko terhadap prospek pertumbuhan ekonomi negara lainnya yang memiliki hubungan dengan kedua negara tersebut.

Dalam konteks pasar modal, berbagai ketidak pastian seperti saat ini bukanlah suatu hal yang baik. Pasar modal merupakan pasar yang dinamis, dimana apabila terjadi gejolak (fenomena) terhadap negara yang memiliki pengaruh besar dalam pasar global seperti Amerika dan China dapat menimbulkan efek dan gejolak di pasar modal global bagi negara lainnya. Maka dalam konteks ini, peneliti akan mencoba melihat efek yang ditimbulkan disebabkan adanya trade war ini sebagai suatu variabel moderating. Adapun dipilihnya trade war sebagai variabel moderating yaitu dengan mengkontruksikan trade war dalam mempengaruhi hubungan terhadap suku bunga Sertifikat Bank Indonesia, inflasi dan kurs valuta asing di negara Indonesia. Adapun akibat yang ditimbulkan dari adanya trade war sebagai suatu kebijakan yang dilakukan oleh pemerintah Amerika terhadap China menyebabkan kekhawatiran ekonomi secara global, yang kemudian berimbas pada terjadinya berbagai fenomena, seperti salah satunya inversi obligasi di Amerika, yaitu kondisi dimana nilai obligasi jangka pendek lebih besar dibandingkan dengan nilai balik obligasi jangka panjang (Publikasi CNBC pada 28 Maret 2019 dengan Judul Hati-Hati, AS di ambang resesi). Akibat kondisi seperti ini akan menyebabkan negara-negara lain yang memiliki hubungan dagang dengan kedua negara merasakan imbasnya. Dengan demikian, proxy yang dikontruksikan oleh peneliti sebagai bagian dari trade war dalam konteks pasar modal yaitu setidaknya terdapat dua proxy, diantaranya tarif The FED dan Indeks Dow Jones. Kedua proxy ini memiliki peran yang cukup penting dalam perekonomian global, dimana ketika Bank Central Amerika mengeluarkan suatu kebijakan dengan menaikkan ataupun menurunkan tarifnya, maka akan berdampak pada respon pasar, termasuk para investor yang menanamkan modalnya di Indonesia. Hubungannya terhadap trade war yaitu kondisi pasar yang tidak memiliki kepastian akan mempengaruhi pasar modal yang ada di Amerika. Dengan demikian, imbas yang ditimbulkan dapat diukur dengan melihat perubahan yang terjadi di pasar modal Amerika, yaitu salah satunya dengan melihat kinerja saham indeks, dan dalam hal ini peneliti menggunakan indeks Dow Jones sebagai indeks yang menjadi proxy trade war untuk mengukur kondisi pasar modal di Amerika.

Berdasarkan model penelitian ini, maka identifikasi masalah dalam penelitian ini yaitu :

1. Apakah suku bunga SBI berpengaruh terhadap kinerja saham Indeks LQ45

2. Apakah kurs valuta asing berpengaruh terhadap kinerja saham Indeks LQ45 
3. Apakah inflasi berpengaruh terhadap kinerja saham Indeks LQ45

4. Apakah suku bunga SBI berpengaruh terhadap kinerja saham Indeks LQ45 dengan trade war sebagai varibel moderating

5. Apakah kurs valuta asing berpengaruh terhadap kinerja saham indeks LQ45 dengan trade war sebagai variabel moderating

6. Apakah inflasi berpengaruh terhadap kinerja saham indeks LQ45 dengan trade war sebagai variabel moderating

Adapun penelitian ini memiliki tujuan, yaitu:

1. Untuk mengetahui apakah suku bunga SBI berpengaruh terhadap kinerja saham Indeks LQ45

2. Untuk mengetahui apakah kurs valuta asing berpengaruh terhadap kinerja saham Indeks LQ45

3. Untuk mengetahui apakah inflasi berpengaruh terhadap kinerja saham Indeks LQ45

4. Untuk mengetahui apakah suku bunga SBI berpengaruh terhadap kinerja saham Indeks LQ45 dengan trade war sebagai varibel moderating

5. Untuk mengetahui apakah kurs valuta asing berpengaruh terhadap kinerja saham indeks LQ45 dengan trade war sebagai variabel moderating

6. Untuk mengetahui apakah inflasi berpengaruh terhadap kinerja saham indeks LQ45 dengan trade war sebagai variabel moderating

Indeks LQ45 adalah indeks likuiditas empat puluh lima buah perusahaan yang selama ini dianggap memiliki kinerja yang dapat dipertanggung jawabkan serta memenuhi kriteria sesuai dengan yang dipersyaratkan oleh manajemen LQ45 (Fahmi, 2014). Indeks LQ45 ini menggunakan metode rata-rata tertimbang (weighted average) dengan rumus Paasche, seperti yang digunakan pada IHSG BEI (Nugroho, 2008).

Suku bunga dapat didefinisikan sebagai tingkat pengembalian aset yang mempunyai risiko mendekati nol. Peningkatan suku bunga membuat nilai imbal hasil dari deposito dan obligasi menjadi lebih menarik, sehingga banyak investor pasar modal yang mengalihkan portofolio sahamnya. Meningkatnya aksi jual dan minimnya permintaan akan menurunkan harga saham dan sebaliknya (Suselo, Djazuli and Indrawati, 2015). Tingkat suku bunga menurut pendapat ahli lainnya yaitu harga yang harus dibayarkan peminjam uang atas pinjaman modal dan hutangnya (Brigham dan Houston, 2009) dan Suku bunga SBI adalah instrumen suku bunga yang dikeluarkan oleh BI untuk mengontrol peredaran uang di masyarakat. Dalam publikasinya, Bank Indonesia menjelaskan bahwa telah melakukan penguatan kerangka operasi moneter dengan melakukan implementasi suku bunga acuan atau suku bunga kebijakan 
baru yaitu BI 7-Day (Reverse) Repo Rate, yang berlaku efektif sejak 19 Agustus 2016, menggantikan BI Rate. Penguatan kerangka operasi moneter ini merupakan hal yang lazim dilakukan di berbagai bank sentral dan merupakan best practice internasional dalam pelaksanaan operasi moneter. Kerangka operasi moneter senantiasa disempurnakan untuk memperkuat efektivitas kebijakan dalam mencapai sasaran inflasi yang ditetapkan.

Menurut Fahmi (2014:557) valuta asing adalah mata uang yang dipakai sebagai alat transaksi yang berbentuk mata uang dari negara lain. Valuta asing tersebut dapat berbentuk kertas dan koin, serta umumnya memiliki nilai yang fluktuatif dipasaran. Kondisi fluktuatif terjadi disebabkan oleh berbagai faktor yang mendorong menguat dan melemahnya nilai tukar mata uang negara yang bersangkutan. Menurut Hanafi (2016), harga suatu mata uang relatif terhadap mata uang lainnya (kurs) sangat tergantung dari kekuatan penawaran (supply) dan permintaan (demand) mata uang tersebut. Nilai tukar mata uang dipercayakan bisa membantu investor dalam meramalkan apa yang akan terjadi dipasar modal, termasuk di Indonesia.

Pengertian Inflasi menurut Tandelilin (2010:342), inflasi adalah kecenderungan terjadi peningkatan pada harga produk secara menyeluruh, sehingga menyebabkan terjadinya penurunan daya beli uang di masyarakat. Sedangkan menurut Putong (2013:417), menyatakan bahwa inflasi adalah proses kenaikan harga-harga umum secara terus menerus. Sedangkan kebalikannya dari inflasi adalah deflasi, yaitu penurunan harga secara terus menerus, akibatnya daya beli masyarakat bertambah besar, sehingga pada tahap awal barang-barang menjadi langka, akan tetapi pada tahap berikutnya jumlah barang akan semakin banyak karena semakin berkurangnya daya beli masyarakat.

Trade war atau perang dagang merupakan suatu fenomena yang terjadi di Negara Amerika, dimana sejak terpilihnya presiden Amerika yaitu Presiden Donald Trump, maka ia berusaha untuk mewujudkan janji kampanyenya untuk membuka lapangan pekerjaan serta membuat perekonomian Amerika bangkit kembali. Maka salah satu kebijakan yang ditempuh yaitu dengan melakukan trade war kepada beberapa negara, yang salah satunya yaitu negara China.

pengertian trade war menurut Mahmoud dalam publikasi jurnal Cairo University, menyatakan bahwa "Trade wars simply refer to thesituation when a country imposes tariffs on other country's imports, so the second countrydecides to impose retaliatory tariffs on the first country, so tariffs here are imposed on the basisof reciprocity"(Mahmoud, 2019). Berdasarkan pengertian ini diketahui bahwa perang dagang merupakan situasi dimana negara melakukan penyesuaian tarif import kepada negara lain dan negara tersebut melakukan balasan dengan penyesuaian tarif kepada 
negara yang tersebut sehingga kedua negara yang terkait saling melakukan pembalasan atas penyesuaian tarif import tersebut.

Adapun penyebab utama terjadinya tradewar sesuai dengan publikasi China Economic Jurnal menyatakan yaitu Three major concerns drove the U.S. into initiating the trade war, and they are (a) the concern that China's chronically large trade surplus was depressing job creation in the U.S.; (b) the concern that China was using illegal and unfair methods to acquire $U$. S. technology at an effectively discounted price; and (c) the concern that China seeks to weaken U.S. national security and its international standing.(Liu and Woo, 2018).

Adapun hipotesis dalam penelitian ini yaitu:

1. Suku bunga SBI berpengaruh signifikan terhadap kinerja saham Indeks LQ45 yang terdaftar di BEI

2. Kurs valuta asing berpengaruh signifikan terhadap kinerja saham Indeks LQ45 yang terdaftar di BEI

3. Inflasi berpengaruh signifikan terhadap kinerja saham Indeks LQ45 yang terdaftar di BEI

4. Suku bunga SBI berpengaruh signifikan terhadap kinerja saham Indeks LQ45 yang terdaftar di BEI dengan trade war sebagai varibel moderating

5. Kurs valuta asing berpengaruh signifikan terhadap kinerja saham indeks LQ45 yang terdaftar di BEI dengan trade war sebagai variabel moderating

6. Inflasi berpengaruh signifikan terhadap kinerja saham indeks LQ45 yang terdaftar di BEI dengan trade war sebagai variabel moderating.

\section{METODE PENELITIAN}

Jenis penelitian yang di gunakan adalah penelitian eksploratif kuantitatif. Menurut Martono (2010) menyatakan bahwa penelitian eksploratif merupakan penelitian pendahuluan dikarenakan penelitian ini mencoba menggali informasi atau permasalahan yang relatif masih baru, dimana gejalan tersebut belum pernah menjadi bahan kajian sebelumnya. Adapun penelitian kuantitatif menitik beratkan pada pengukuran dan analisis hubungan sebab akibat antara bermacam-macam variabel. (Wibisono, 2017: 10). Penelitian ekslporatif ini dimaksudkan karena dalam penelitain terdahulu, dikemukanan berbagai efek dari adanya perang dagang dalam konteks ekonomi makro dan kebijakan international, sedangkan dalam penelitian ini bertujuan untuk mengukur hubungannya dengan variabel yang digunakan dalam konteks pasar modal.

Penelitian dilakukan dengan mengambil data publikasi atau sekunder dari berbagai lembaga dan website untuk data laporan Indeks LQ45, laporan bulanan suku bunga Sertifikat Bank Indonesia, inflasi, dan kurs valuta asing serta indikator trade war yang diambil dari website Badan Pusat Statistik, 
Bank Indonesia, Bursa Efek Indonesia, pusatdata.kontan.co.id dan id.investing.com untuk periode tahun 2016 s/d 2018.

Tempat penelitian dilakukan pada perusahaan LQ45 yang terdaftar di bursa efek Indonesia melalui situs www.idx.co.id sedangkan waktu penelitian dimulai bulan Januari 2016 sampai dengan Desember 2018. Ruang lingkup penelitian ini difokuskan pada faktor-faktor yang diduga dapat mempengaruhi pergerakan Indeks Kinerja Saham, dan faktor-faktor tersebut yaitu tingkat suku bungan SBI, inflasi dan kurs valuta asing serta trade war sebagai variabel moderating. Jangka waktu penelitian selama 3 tahun, dimulai tahun 2016 sampai tahun 2018 .

Berdasarkan penelitian ini karena jumlah populasinya tidak lebih besar dari 100 orang responden, maka peneliti mengambil 100\% jumlah populasi yang ada yaitu sebanyak 36 sampel perusahaan. Dengan demikian penggunaan seluruh populasi tanpa harus menarik sampel penelitian sebagai unit observasi disebut sebagai teknik sensus.

Teknik pengumpulan data yang dilakukan adalah metode dokumentasi dari sumber data sekunder dengan mengumpulkan, mencatat, dan mengolah data yang berkaitan dengan penelitian. Data yang dianalisis dalam penulisan ini bersumber data sekunder yang diambil untuk diteliti/diproses meliputi suku bunga SBI, inflasi, kurs valuta asing dan trade war yang bersumber dari publikasi Bursa Efek Indonesia, Bank Indonesia (BI),
Badan Pusat Statistik, pusatdata.kontan.co.id dan id.investing.com dari bulan Januari 2016 sampai dengan Desember 2018. Data yang dikumpulkan adalah data sekunder rata-rata bulanan dari 33 emiten perusahaan sampel untuk mendapatkan Kinerja Saham Indeks LQ45 setiap bulannya dari bulan Januari 2016 sampai dengan Desember 2018. Pemilihan tahun 2016 sebagai awal disebabkan pada tahun tersebut baru dilantiknya presiden Donald Trump sebagai presiden Amerika yang memulai perang dagang terhadap beberapa negara di dunia.

Adapun metode analisis data yang digunakan dalam penelitian ini antara lain pengujian asumsi klasik yang kemudian dilanjutkan dengan analisis regresi linier berganda dan uji hipotesis denganuji parsial (uji-T), uji simultan (uji-F) serta uji residual untuk variabel moderating dengan menggunakan software SPSS (Statistical Product and Service Solutions).

\section{HASIL DAN PEMBAHASAN}

Indeks LQ45 merupakan indikator indeks saham di Bursa Efek Indonesia (BEI) yang terdiri atas 45 perusahaan (emiten) yang dipilih berdasarkan kriteria likuiditas dan kapitalisasi pasar serta menerbitkan saham yang termasuk dalam kategori saham bluechip. Output statistik deskriptif mengolah data penelitian sebanyak 36 data sejak tahun 2016 sampai 2018. Adapun tampilan data deskriptif sebagai berikut: 
Tabel 2

Deskriptif

\begin{tabular}{|l|r|r|r|c|c|}
\hline & Mean & Min & Max & $\begin{array}{c}\text { Std. } \\
\text { Deviation }\end{array}$ & N \\
\hline $\begin{array}{l}\text { kinerja } \\
\text { saham }\end{array}$ & 936,47 & 799,9 & 1105 & & \\
indeks & 79 & 9 & 76 & 72,53862 & 36 \\
Sbi & 5,0833 & 4,25 & 6 &, 78376 & 36 \\
kurs & 13665, & 1299 & 15227 & & \\
valuta & 8056 & & 549,72761 & 36 \\
asing & & & & \\
Inflasi & 3,5125 & 2,79 & 4,45 &, 44440 & 36 \\
dow & 21653, & 1646 & 26458 & 3104,38492 & 36 \\
jones & 6708 & 6,30 &, 31 & \\
\hline
\end{tabular}

Uji Normalitas

Tabel 3

Hasil uji normalitas

One-Sample Kolmogorov-Smirnov Test

\begin{tabular}{|c|c|c|}
\hline & & $\begin{array}{l}\text { Unstandardiz } \\
\text { ed Residual }\end{array}$ \\
\hline \multicolumn{2}{|l|}{$\mathrm{N}$} & 36 \\
\hline Normal & Mean & ,0000000 \\
\hline Parameters ${ }^{\mathrm{a}, \mathrm{b}}$ & Std. Deviation & 31,23073905 \\
\hline Most Extreme & Absolute &, 125 \\
\hline \multirow[t]{2}{*}{ Differences } & Positive &, 125 \\
\hline & Negative &,- 073 \\
\hline \multicolumn{2}{|l|}{ Test Statistic } &, 125 \\
\hline \multicolumn{2}{|c|}{ Asymp. Sig. (2-tailed) } &, $166^{\mathrm{c}}$ \\
\hline
\end{tabular}

a. Test distribution is Normal.

b. Calculated from data.

c. Lilliefors Significance Correction.

Hasil output SPSS V.22 dalam tabel di atas ini uji normalitas data, menguji 36 data penelitian berdistribusi normal melalui pengujian One-Sample KolmogorovSmirnov Test karena nilai p-value > 0,05 yaitu nilai sig Asymp. Sig. (2-tailed) lebih besar dari 0.05 atau Sighitung 0,166>0,05, artinya memenuhi persyaratan uji asumsi klasik dan penelitian dapat dilanjutkan karena data penelitian bersdistribusi normal.

\section{Uji Multikolinearitas}

Tabel 4

Hasil uji multikolinearitas

\begin{tabular}{|ll|r|r|}
\hline \multirow{2}{*}{ Model } & \multicolumn{2}{|c|}{ Coefficients $^{\mathbf{a}}$} \\
\cline { 2 - 4 } & Collinearity Statistics \\
\hline 1 & Tolerance & \multicolumn{1}{c|}{ VIF } \\
\cline { 2 - 3 } & Consta & & \\
SBI & & \\
KURS &, 269 & 3,723 \\
INF &, 171 & 5,853 \\
TW &, 686 & 1,457 \\
&, 184 & 5,426 \\
\hline
\end{tabular}

a. Dependent Variable: KSI

Adapun hasil pengolahan data penelitian untuk Uji multikolinearitas ditunjukkan dalam tabel 4 semua variabel memiliki nilai VIF $<10$ dan tingkat torelansi lebih kecil dari angka 1 (satu), artinya bahwa seluruh variabel tidak terjadi multikolinieritas atau tidak ada variabel yang multikolinieritas.

\section{Uji Autokorelasi}

Tabel 5

Uji Run Test

\begin{tabular}{|l|r|}
\hline & $\begin{array}{c}\text { Unstandardized } \\
\text { Residual }\end{array}$ \\
\hline Test Value & $-4,83755$ \\
Cases < Test Value & 18 \\
Cases > = Test Value & 18 \\
Total Cases & 36 \\
Number of Runs & 11 \\
Z & $-2,536$ \\
Asymp. Sig. (2-tailed) &, 011 \\
\hline
\end{tabular}

a. Median

Selanjutnya berdasarkan hasil uji runs test di atas, maka dapat diketahui bahwa nilai Asymp. Sig (2-tailed) sebesar 0,011, 
sehingga memiliki nilai lebih besar dari 0,05, maka dapat disimpulkan bahwa model tidak memiliki gejala autokorelasi.

\section{Uji t Parsial}

Tabel 6

Hasil uji t Parsial

\begin{tabular}{|c|c|c|c|c|c|}
\hline & & Coefficie & & & \\
\hline \multirow{2}{*}{ Model } & \multicolumn{2}{|c|}{$\begin{array}{l}\text { Unstandardized } \\
\text { Coefficients }\end{array}$} & $\begin{array}{c}\text { Standard } \\
\text { ized } \\
\text { Coefficie }\end{array}$ & \multirow{2}{*}{$\mathrm{t}$} & \multirow{2}{*}{ Sig. } \\
\hline & B & $\begin{array}{l}\text { Std. } \\
\text { Error }\end{array}$ & Beta & & \\
\hline $\begin{array}{ll}1 & \text { (Const } \\
\text { ant) }\end{array}$ & $\begin{array}{r}1704,75 \\
7\end{array}$ & 241,345 & & 7,064 & ,000 \\
\hline SBI & 9,747 & 13,809 & ,105 & ,706 & ,486 \\
\hline KURS &,- 105 & ,025 &,- 794 & $-4,246$ & ,000 \\
\hline INF & $-10,405$ & 15,237 &,- 064 &,- 683 & ,500 \\
\hline TW & ,030 & ,004 & 1,287 & 7,144 & ,000 \\
\hline
\end{tabular}

a. Dependent Variable: KSI

Uji Nilai t

\section{Uji Koefisien Determinasi $\left(\mathbf{R}^{2}\right)$}

Tabel 7

Hasil uji koefisiedn determinasi $\left(\mathrm{R}^{2}\right)$

\begin{tabular}{|l|c|r|r|c|}
\hline \multicolumn{5}{|c|}{ Model Summary $^{\mathbf{b}}$} \\
Mo & & & Adjusted & Std. Error of the \\
del & R & R Square & R Square & Estimate \\
\hline 1 &, $903^{\mathrm{a}}$ &, 815 &, 791 & 33,18451 \\
\hline
\end{tabular}

a. Predictors: (Constant), TW, SBI, INF, KURS

b. Dependent Variable: KSI

Dari pengujian regresi yang dilakukan, diperoleh hasil Uji R Square sebesar 0,815 dan nilai Adjust R Square sebesar 0.903, hal ini berarti $81,5 \%$ variasi dari variabel independen dan terhadap variable dependen, artinya suku bunga SBI, kurs valuta asing dan inflasi serta trade war mempunyai pengaruh sebesar $81,5 \%$ terhadap kinerja saham indeks sedangkan $18,5 \% \quad(100 \%-81,58 \%=18,5 \%)$ dijelaskan oleh sebab-sebab yang lain diluar model penelitian ini.

\section{PEMBAHASAN}

Suku bunga SBI berpengaruh signifikan terhadap kinerja saham Indeks LQ45 yang terdaftar di BEI

Berdasarkan hasil pengujian yang telah dilakukan menggunakan SPSS, diketahui bahwa Suku Bunga SBI nilai signifikansi sebesar 0,486 lebih besar dari nilai $\alpha(0,05)$ atau Sig. $t_{\text {hitung }}<0,05$ yakni $0,486>0,05$ sehingga dari hasil tersebut dapat disimpukan bahwa Hipotesis Pertama (H1) tidak diterima artinya Suku Bunga SBI berpengaruh tidak signifikan terhadap Kinerja Saham Indeks. Hasil ini bertentangan dengan teori yang menyatakan bahwa semakin tingginya suku bunga Bank, akan menyebabkan uang yang beredar di pasar modal beralih kepada sektor perbankan sehingga menimbulkan pengaruh yang negatif terhadap kinerja saham indeks.

\section{Kurs valuta asing berpengaruh signifikan} terhadap kinerja saham Indeks LQ45 yang terdaftar di BEI

Berdasarkan hasil pengujian SPSS, diketahui bahwa Nilai signifikasi variabel kurs valuta asing sebesar 0,000 lebih kecil dari nilai $\alpha(0,05)$ atau Sig. $t_{\text {hitung }}<0,05$ yakni $0,000<0,05$ dan $t_{\text {hitung }}>t_{\text {tabel }}$ dari hasil tersebut dapat disimpulan bahwa kurs valuta asing berpengaruh dan signifikan terhadap kinerja saham indeks. Hal ini disebabkan karena ketika terjadinya feneomena kenaikan atas valuta asing akan berdampak negatif 
terhadap nilai indeks saham. Kurs valuta asing mengalami kenaikan di tahun ini, sehingga memberian dampak yang negatif terhadap kinerja saham.

Inflasi berpengaruh signifikan terhadap kinerja saham Indeks LQ45 yang terdaftar di BEI

Berdasarkan Nilai signifikasi variabel inflasi menunjukkan bahwa nilai $\beta-10,405$ dan nilai sig. thitung sebesar 0,500 atau nilai $t_{\text {hitung }}>0,05$ yakni $0,500>0,05$. Hasil pengujian tersebut dapat disimpulan bahwa Hipotesis ketiga (H3) tidak diterima artinya inflasi berpengaruh tidak signifikan terhadap Kinerja Saham Indeks.

Suku Bunga SBI berpengaruh signifikan terhadap kinerja saham Indeks LQ45 yang terdaftar di BEI dengan trade war sebagai varibel moderating

Pengujian moderasi residual menunjukkan bahwa variabel trade war adalah sebagai variabel moderating, dengan nilai koefisien parameter regresi pada variabel Belanja modal $\beta$ sebesar $-3,123$ dan nilai signifikansi

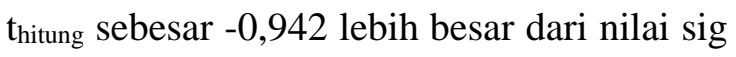
$\alpha(0,05)$ yaitu $0,353>0,05$ artinya bahwa variable trade war memoderasi hubungan antara suku bunga SBI dengan kinerja saham indeks tetapi tidak signifikan. Berdasarkan hasil tersebut, maka dapat digolongkan sebagai kategori pure moderasi, dimana pengaruh variabel $\mathrm{X} 4$ nya tidak signifikan namun moderating efeknya berpengaruh.

Kurs valuta asing berpengaruh signifikan terhadap kinerja saham Indeks LQ45 yang terdaftar di BEI dengan trade war sebagai varibel moderating

Pengujian moderasi residual menunjukkan bahwa variabel trade war adalah sebagai variabel moderating, dengan nilai koefisien parameter regresi pada variabel Belanja modal $\beta$ sebesar $-0,001$ dan nilai signifikansi

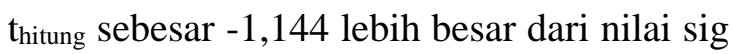
$\alpha(0,05)$ yaitu $0,261>0,05$ artinya bahwa variable trade war memoderasi hubungan antara kurs valuta asing dengan kinerja saham indeks tetapi tidak signifikan. Berdasarkan hasil tersebut, maka dapat digolongkan sebagai kategori pure moderasi, dimana pengaruh variabel $\mathrm{X} 4$ nya tidak signifikan namun moderating efeknya berpengaruh.

Inflasi berpengaruh signifikan terhadap kinerja saham Indeks LQ45 yang terdaftar di BEI dengan trade war sebagai varibel moderating

Pengujian moderasi residual menunjukkan bahwa variabel trade war adalah sebagai variabel moderating, dengan nilai koefisien parameter regresi pada variabel Belanja modal $\beta$ sebesar $-1,148$ dan nilai signifikansi

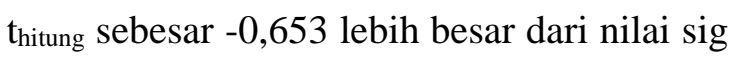
$\alpha(0,05)$ yaitu $0,518>0,05$ artinya bahwa variable trade war memoderasi hubungan antara inflasi dengan kinerja saham indeks tetapi tidak signifikan. Berdasarkan hasil tersebut, maka dapat digolongkan sebagai kategori pure moderasi, dimana pengaruh variabel X4 nya tidak signifikan namun moderating efeknya berpengaruh. 


\section{PENUTUP}

\section{Kesimpulan}

1. Kesimpulan Suku bunga SBI memberikan dampak yang tidak signifikan terhadap kinerja saham indeks terhadap perusahaan yang terdapat di dalam bursa efek Indonesia

2. Kurs valuta asing memberikan dampak yang signifikan terhadap kinerja saham indeks perusahaan yang terdapat di dalam bursa efek Indonesia

3. Inflasi memberikan dampak yang tidak signifikan terhadap kinerja saham indeks perusahaan yang terdapat di dalam bursa efek Indonesia

4. Variabel trade war memiliki memoderating efek terhadap hubungan suku bunga SBI dan kinerja saham indeks, namun nilainya tidak signifikan sehingga dapat digolongkan sebagai pure moderasi, sebab perubahan yang terjadi di dalam suku bunga SBI tidak cenderung diakibatkan adanya perang dagang antara Amerika dan China

5. Variabel trade war memoderating efek terhadap hubungan kurs valuta asing dan kinerja saham indeks, namun nilainya tidak signifikan sehingga tergolong sebagai pure moderasi, sebab perubahan yang terjadi di dalam kurs valuta asing tidak cenderung diakibatkan adanya perang dagang antara Amerika dan China

6. Variabel trade war memiliki memoderating efek terhadap hubungan inflasi dan kinerja saham indeks, namun nilainya tidak signifikan sehingga tergolong sebagai pure moderasi, sebab perubahan yang terjadi di dalam kurs valuta asing tidak cenderung diakibatkan adanya perang dagang antara Amerika dan China

\section{Saran}

Adapun yang menjadi saran dalam penelitian ini yaitu:

1. Perlunya persiapan menghadapi tantangan kedepan atas ancaman trade war yang lebih luas terhadap pasar Indonesia

2. Perlunya kewaspadaan atas barang-barang impor dari China yang beralih dari pasar Amerika dan Eropa menuju negara berkembang di Asia

3. Diperlukannya perluasan kajian dan kebijakan atas penelitian yang telah dibuat guna perbaikan kedepannya.

\section{DAFTAR PUSTAKA}

Brigham, E., 2013. F dan Joel F. Houston. 2001. Manajemen Keuangan, pp.2327.

Irham, F., 2014. Manajemen keuangan perusahaan dan pasar modal.

Hanafi, M., 2016. Manajemen Keuangan Edisi Kedua. Cetakan Pertama. Yogyakarta: BPFE.

Liu, T. and Woo, W.T., 2018. Understanding the US-China trade war. China Economic Journal, 11(3), pp.319340.

Mahmoud, A. M., 2019. "US-China Trade War 2018. Faculty of Economics and Political Science, Cairo University Trade war between US and China Ahmad Medhat (51150171)", (January).

Martono, N., 2010. Metode penelitian kuantitatif: Analisis Isi dan Analisis Data Sekunder (sampel halaman gratis). RajaGrafindo Persada. 
Nugroho, H., 2008. Analisis Pengaruh Inflasi, Suku Bunga, Kurs dan Jumlah Uang Beredar terhadap Indeks LQ45 (Studi Kasus Pada BEI Periode 20022007) (Doctoral dissertation, program Pascasarjana Universitas Diponegoro).

Putong, I., 2013. Economics pengantar mikro dan makro. Jakarta: Mitra Wacana Media, 48.

Suselo, D., Djazuli, A. and Indrawati, N.K., 2015. Pengaruh Variabel Fundamental dan Makro Ekonomi terhadap Harga saham (Studi pada perusahaan yang masuk dalam Indeks LQ45). Jurnal Aplikasi Manajemen, 13(1), pp.104-116.

Tandelilin, E., 2010. Portofolio dan Investasi: Teori dan aplikasi. Kanisius.

Wibisono, C., 2017. Metode Penelitian Berbasis Kuantitatif dan Kualitatif. K-Media. Yogyakarta. 